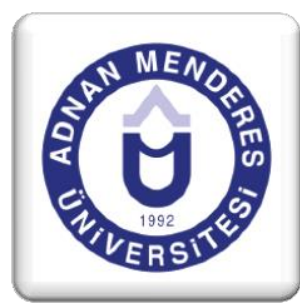

\title{
Çocuk ve Gençlik Edebiyatında Hümanizm Kavramı ve Şafakta Yanan Mumlar Örneği
}

\section{Concept of Humanism in}

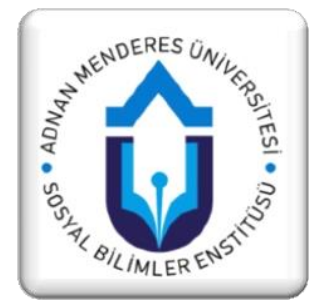

\author{
Children's and Youth Literature and
}

Example of Şafakta Yanan Mumlar

Tahir AKIŞLI ${ }^{1}$

\section{Özet}

Çocuklar ve gençler için oluşturulmuş edebî yapıtların, muhataplarına edebî zevk vermelerinin yanında eğitici, yetiştirici ve hayata hazırlayıc işlevleri de vardır. Bu işlevlerin gerçekleşebilmesi için eserler, belirli anlayışlar çerçevesinde kaleme alınmaktadır. Hümanist anlayış da bu çerçevenin içine girmektedir. Hümanizm, insanı özgürleştirme amacını taşıyan, merkezine insana fayda ve insan hoşnutluğunu koyan bir anlayıştır. Bunun yanında hümanizm, evrensele açılan kapıdır. Çocuk ve gençlik edebiyatı yazarlarının ulaşmak istediği amaçlardan biri de evrenselliktir. Sıraladığımız nitelikler hümanizmin çocuk ve gençlik edebiyatı ürünlerinde kullanılma sebeplerindendir. Biz, bu çalışmamızda hümanizm kavramının çocuk ve gençlik edebiyatındaki yerini ve önemini Serpil Ural'ın Şafakta Yanan Mumlar adlı romanından ve bu romandaki kurgudan yola çıkarak incelemeye çalışacağız.

Anahtar Kelimeler: Çocuk Edebiyatı, Gençlik Edebiyatı, Çanakkale Savaşları, Hümanizm, Roman Sanatı

\section{Abstract}

Literary arts for children and youth, give pleasure but at the same time they also have educational functions. Literary arts also help readers to get prepared for life. To fulfill these functions, the literary arts are written according to certain intelligence. Also humanism is in this content. Humanism helps to free the human beings, it also takes the human into into its center to give pleasure and profit. Humanism is a door, opening to the universe. Writers of child and youth literary arts have got certain aims. One of their aims is being universal. The qualities we have mentioned above, are the reasons why humanism is used in child an youth literary arts. We will try to study the place and the importance of humanism on child and youth literary arts on Serpil Ural's novel called "Şafakta Yanan Mumlar".

Keywords: Children Literature, Youth Literature, War of Çanakkale, Art of Novel

\footnotetext{
${ }^{1}$ Adnan Menderes Üniversitesi Sosyal Bilimler Enstitüsü Türk Dili ve Edebiyatı A.B.D. Yeni Türk Edebiyatı Bilim Dalı Yüksek Lisans Öğrencisi, tahirakisli@hotmail.com
} 


\section{GİRIŞ}

Serpil Ural'ın Şafakta Yanan Mumlar adlı eseri, kendine konu olarak Çanakkale Savaşını seçmiştir. "Roman, tarihî gerçekliği yani Çanakkale Muharebelerini bir fon olarak kullanıp bu muharebeleri bir hareket noktası olarak ele almıştır." (Mat, 2007: 84). Türk siyasî ve sosyal hayatı bakımından çok önemli bir yere sahip olan Çanakkale Muharebelerine, ne yazık ki, edebiyatımızda gereken önem verilmemiştir. Oysaki Türk Milleti, tarihî süreç içerisinde yaşadığı büyük ve önemli olaylarda destanlar yaratmıştı. Pertev Nail Boratav, destanların teşekkülünde üç safha belirttikten sonra, "Türk destanlarının çoğu ikinci safhada destan halkası halinde kalmıştır. Bunun sebebi ise... Türkler birçok destan olabilecek olayları defalarca yaşamışlardır. Bir destan halkalar halindeyken, ikinci bir destana konu olabilecek bir olay ortaya çıkmışır. Böylece eski destanlara son şeklini vermeye firsat kalmamıştır." der (Boratav,2000: 39). Edebiyatımızda Çanakkale Muharebelerine gösterilen ilginin azlığını da bu sebebe bağlamak yanlış olmasa gerektir. Çanakkale Muharebelerinin de kaderi, daha önce yaratılan Türk destanlarına benzer bir durum sergilemektedir. Çanakkale Muharebelerinin ardından başlayan Ulusal Kurtuluş Savaşı, Çanakkale Muharebelerini bir nebze unutturmuştur, “... art arda gelen savaşların ve kazanılan zaferlerin de etkisi söz konusudur. Nitekim, Çanakkale Muharebelerinden neredeyse hemen sonra başlayan Kurtuluş Savaşı ve bu savaşın ardından kazanılan büyük zafer, bir bakıma edebiyatçıların dikkatini daha çok bu olaya yöneltmelerine neden olmuştur." (Mat, 2007: 81). Bu sebebin yanında, Celal Mat'ın tespitiyle, ülkemizde , “...büyük ölçüde bir "harp edebiyatı" geleneğinin olmaması" (Mat, 2007: 81) da etkili olmuştur. Bu açıdan bakıldığında Serpil Ural'ın Şafakta Yanan Mumlar romanı, bakir bir alanda kaleme alınmış bir eser olarak nitelendirilebilir. Roman; "ölenin öldürenden farklı olmadığını vurgulamak, ölenin de öldürenin de insan olduğunu göstermek, savaşların sonunda kazanan tarafların bile çok şey kaybettiğini ve her zaferin perde arkasında yoğun acıların yaşandığını anlatmak" (Ural, 2006: 5-6) isteğiyle kaleme alınmıştır.

Romanın bir diğer özelliği de bir gençlik romanı olmasıdır. Şafakta Yanan Mumlar bir gençlik romanı olmasına rağmen 1997'de Türkiye İş Bankası Çocuk Edebiyatı büyük ödülünü kazanmıştır. Bu durum, romanın incelenmesinin çocuk ve gençlik edebiyatının sınırları dahilinde yapılmasını zorunlu kılar. Çocuk ve gençlik edebiyatının ise, "yetişkinler için oluşturulan edebiyat gibi uzun bir geçmişi ve geçirdiği bir birikim dönemi yoktur." (Yardımc1 ve Tuncer, 2002: 10) Öyle ki; "16. yy'a gelinceye değin dünyanın hiçbir ülkesinde çocuklar düşünülerek kaleme alınmış hiçbir edebiyat ürünü görülmemektedir." (Yardımcı ve Tuncer, 2002: 10). Bu duruma rağmen çocuk ve gençlik edebiyatının sınırları günümüzde belirlenmiş, kavramsal çerçevesi çizilmiştir. Çocuk ve gençlik edebiyatıyla ilgili yapılan incelemelerde, bu tür kitapların sadece içerik özellikleri belirtilmekle kalınmamış, dış yapı(kullanılan kağıt türü, yazının boyutu, yazı tipi, resimlendirme, ciltleme) özelliklerinin de nasıl olması gerektiği belirtilmiştir. Yazımızda bu özelliklerin tümünü sıralamak gibi bir niyetimiz yok. Ancak konumuzla ilgili olan kısımlar üzerinde duracağız.

\section{HÜMANIZM KAVRAMI}

Hümanizm kelimesi her ne kadar batı kaynaklı da olsa bu terim ile ifade edilen içerik, Doğu toplumlarında da çok uzun yıllardan beri görülmektedir. Nitekim, Batıda hümanizm, "genel olarak akıllı insan varlı̆̆ını tek ve en yüksek değer kaynă̆ı olarak gören, bireyin yaratıcı ve ahlaki gelişiminin, rasyonel ve anlaml bir biçimde, doğaüstü alana hiç başvurmadan, doğal yoldan gerçekleştirebileceğini belirten ve bu çerçeve içinde insanın doğallığını, özgürlü̆̈̈̈nü ve etkinliğini ön plana çıkartan felsefi akım” (Cevizci, 1999: 431)olarak tanımlanır. "Orta Çăg İslam düşüncesi ve bu düşüncenin önemli şahsiyetlerinin (İbni Rüsst, İbni Sina, Farabi vb.) eserleri, bu eserlerdeki İlk Çăg felsefesine ait yorumlar ile İslam kültür ve medeniyetinin Batılılarca tanınmasının, hümanizm, Rönesans ve reformun oluşum ve gelişiminde önemli rolü olduğunu" (Çetişli, 2012: 49) da gözden kaçırmamak gerekir. Biz, yazımızın devamında hümanizm kavramını, salt batı kaynaklı bir düşünce sistemi olarak değil doğu düşüncesinin de aydınlattığ 1 ve içinde doğu düşünce sistemi ile batı düşünce sisteminin harmanlandığ bir kavram olarak kullanacağız. 
Hümanizm kelimesi ilk olarak "Friedrich Immanuel Niethammer adında pek taninmayan bir Alman pedagogu" (Zekiyan, 1982: 15) tarafından kullanılmıştır. "Humanitas, humanus sıfatının "human" gövdesinden soyutlayıcı -itas eki ile elde edilmiş olup, biçimsel yapı açısından, Latin dilinde doğmuş bir terimdir... Göründüğ̈̈ en eski belge, İ.̈̈ 83-84 yıllarına ait olup Rhetorica ad Herennium(Herenium'a ait belagat yazıları) adl, yazarı belli olmayan bir yapıttır" (Zekiyan, 1982: 17). Büyük Roma hatibi olan Marcus Tullius Cicero, hümanizmin başlıca şu öğeleri içermesi gerektiğini belirtir: "bilgi, kültür, ahlak ve ruh eğitimi, terbiye ve nezaket, kibarlık, ruh asaleti ve yüceliği, haysiyet, iyilik, iyi niyetlilik, özveri, adalet, eli açıklık, kadirbilirlik, arkadaş ruhlu olmak, şen ve neşeli olmak, şakacı ve nükteci olmak, ölçülü olmak, zevk sahibi olmak..." (Zekiyan, 1982:17) Hümanizme bağlı olarak zikredilen bu öğeler, aslında her insanda bulunması gereken değerlerdir. Dikkat edilirse yukarıda zikredilen özellikler, bizi, evrensel anlamda bir insana ve dolayısıyla da evrenselliğe götürmektedir. Yapılan öğe sıralamasında, bu öğelerin kimlerde bulunup bulunamayacağı değil, evrensel insan düşünülmüştür. Yine bu konuyla ilgili olarak söylenmiş;;

\title{
"Hak kendini halka bildirmek için
}

Insanı kendine timsal eyledi"

Bektaşi nefesi de tek tek insanlar yerine, evrensel insanı anlatma gayretindedir. Evrensel anlamda insanı anlatan, insan sevgisinin yüceliğini, Türkçesi'nin erişilmez güzelliğiyle süsleyen Yunus Emre de;

\author{
"Yitmiş iki millete birliğile bakmayan \\ Şer'ile evliyasa hakikatde âsidir" (Tan, 1995:342), \\ "Yitmiş iki millete kurban ol âşılksan \\ Tâ âşılklar safinda tamâm olasin sâdık” (Tan, 1995:343)
}

şeklinde evrenselliği, yetmiş iki millet ifadesiyle somutlaştırmıştır. Onun gözünde yetmiş iki millet de birdir. Aynı şekilde İlhamî de bir şiirinde;

\section{"Kendi noksanını bilip ârif ol}

Kimsenin aybını gözetme gönül

Yetmiş üç millete bir nazarla bak

Hak sevmiş yaratmış, söz etme gönül” (Tan, 1995:343-44)

diyerek, insana bakışın bir olması gerektiğini dile getirmiştir. Bilindiği üzere batı düşünce sistemi, "eski Grek-Latin kültür, medeniyet ve inançlarıyla olan bağlarını koparmış, tamamiyle Hıristiyanlığın belirlediği skolastik bir düşünce dünyası içinde" (Çetişli, 2010: 48) kendini var etmeye çalışıyordu. Hümanizm ise eski Grek-Latin kaynaklarına rücû ederek varlığını ortaya çıkarmıştır. Doğu düşünce sistemi dahilindeki hümanizm kavramı da kendisini, birincil kaynak olarak gördüğü Kur'an-1 Kerîm'de var etmiştir. İbrahim Ma'şukî'nin;

\section{"Tasavvuf anlamaktır yetmiş iki milletin dilin}

Tasavvuf âlem-i akla Süleyman olmağa derler” (Tan, 1995:344)

beyti bu durumu açıkça ifade eder. Burada ifade edilmesi gereken batıda ve doğuda farklı kaynaklara dayanan hümanizm kavramının anlam olarak aynı yerde buluştuğudur: İnsanın birliği. Dünyanın neresinde olursa olsun, herhangi bir dinî inanca bağlı olsun veya olmasın, hangi ırka bağlı olursa olsun, hangi cinsiyete bağlı olursa olsun, insanın birliği... Kısacası hümanizm, "insanda merkezini bulan ve insanla bütünleşen bir yaşam ve evren anlayışı olarak tanımlanabilir." (Zekiyan, 1982: 1). Bu inancın bizi götürdügü yer de birdir: evrensellik.

Hümanizm, bir insan ülküsünü dile getirirken aynı zamanda insana yönelen bir eğitim sistemi anlamını da taşır. $\mathrm{Bu}$, hümanizmin eğitsel bir işlevinin olduğunu da ortaya koymaktadır. Söz konusu eğitim olunca, bu eğitimin verilmesi gereken birinci sıradaki kişiler ise çocuklar ve gençlerdir. "İnsan"1, "insanlık"1 anlayan çocuklar ve gençler, hem kendilerini hem de çevrelerini daha iyi anlamış 
olacaklardır. Dünyaya ve hayata yukarıda sıraladığımız niteliklerle bakmaya çalışan çocuklar ve gençler, ileride bu nitelikleri kendi kişiliklerine de yediren birer birey olacaklardır.

"Bir insan ülküsünü dile getiren humanitas, doğal olarak, aynı zamanda bu ülküye göre ve ona yönelen bir eğitim yöntemi de demektir. Hatta bir bakıma, bu ülkü bir eğitim yöntemidir. Bu eğitimin, özellikle akla hitap eden, bilgi ve bilimle ilgili yönlerini göstermek üzere, Cicero, studia humanitatis (insanlı ögrenimi) veya studia humanitatis et litterarum (insanllk ve edebiyat öğrenimi) deyimlerini kullanır ve bunlarla ilgili olarak şu tanımı verir: çocuğu yetiştirip insanlığa eriştiren yöntemler..." (Zekiyan, 1982: 18)

\section{3. ÇOCUK ve GENÇLİK EDEBIYYATINDA HÜMANIST BAKIŞ AÇISI}

Edebiyat, hayatı anlamlandırma çabasıdır. Edebiyat, bir çabadır. Bu çabanın sonucunda ulaşılmak istenen, yani edebî eserin amaçladığı ise, "insana özgü bazı değer ve niteliklerin yerleşip kökleşmesi, toplumsal yaşamın ve çă̆ın gerektirdiği değerlerin benimsenmesidir." (Kavkav, 1994:6). Özellikle alıntıda da belirttiğimiz, "insana özgü bazı değer ve niteliklerin yerleşip kökleşmesi" ifadesi, çocuk ve gençlik edebiyatı ürünlerinde, hümanist bir bakış açısının kullanılmasını gerektirir. Çocuk ve gençlik edebiyatı ürünleri muhataplarını hayata hazırlarken onların hayal dünyalarını etkiler; çocuğun ve gencin kültürel ve ahlakî gelişimine katkıda bulunur. İçinde bulunduğu toplumun kültürel değerlerini, okuyucusunun ilgi duyacağı şekilde ele alır; çünkü hayata hazırladığı okuyucusu, ileride bu kültür mirasının üzerinde hayatını sürdürecektir. Bu bakımdan çocukluk ve gençlik çağlarında edinilecek bu türden bilgiler, çocuğun ve gencin ileriki zamanda hayata uyum sağlamasını kolaylaştıracaktır. Çocukluk ve gençlik dönemlerinde okunan "hikaye ve romanlar, çocukların sınırlı hayat tecrübelerini zenginleştirir, türlü insan tipleri üzerinde düşünmelerine imkan sağlar, geliştirmekte oldukları değer yargılarının daha açıklık kazanmasına yardımcı olur; böylece çocuklar içinde yaşadıkları toplumsal ve kültürel ortama daha kolay uyum sağlar." (Oğuzkan, 2003: 98). Bu dönem içerisinde çocuk ve gence evrensel değerler kavratılmaya çalışılmalıdır. Nitekim bu yaşlarda edinilen bu türden bilgiler daha kolay içselleştirilebilmektedir. Kısacası çocuk ve gençlik edebiyatı ürünlerinde "evrensel değerlere yer verilmeli ve bu ürünler çocuğu rasyonel düşündürmeye yöneltmelidir." (Demircan, 2006: 15) Bunun dışında metinlerde içerik olarak "aşırı politik, ideolojik... çağrışımlara meydan verilmemelidir... Anlatılan kişi, olay ve durumlar, çocuğun iç dünyasında çelişkilere neden olmamall; karamsarlığa, ümitsizliğe ve yılgınlı̆̆a yol açmamalıdır." (Gökçe ve Sis, 2011:1928).Tüm bu söylediklerimizden sonra diyebiliriz ki çocuk ve gençlik edebiyatı ürünleri herhangi bir konuyu herhangi bir edebî formda anlatırken hümanist anlayışa bağlı kalmalıdır. Çocuk ve gencin ruhsal gelişimi açısından bu tutum elzemdir.

\section{4. ŞAFAKTA YANAN MUMLAR'DA KURGULANAN BENZERLIKLER ve HÜMANIZM ALGISI}

Türk gençliğine geçmişlerini hatırlatmak isteyen Serpil Ural, Şafakta Yanan Mumlar adlı eserinde hümanist bir bakış açısı sergilemektedir. Bu tutum romanın kurgusuna da etki etmiştir. Verilmek istenen, dünyanın neresinde olursa olsun insanların ortak duyguları, değerleri ve hassasiyetleri vardır, mesajı romanın kurgusunda yazarı ister istemez çeşitli denkliklere götürmüş ve bu sayede romanın mesajı pekiştirilmiştir.

Şafakta Yanan Mumlar'da biri Türk diğeri Avustralyalı iki aile ele alınmıştır. Avustralyalı aile, Tilly adında bir büyük anne, büyükannenin Norma adındaki kızı ve Norman'nın kızı Peggy'den oluşmaktadır. Bu ailenin bireylerinden Çanakkale Savaşı'nda bulunanlar vardır. Bunlar da Tilly'nin babası Frank, Frank'ın kardeşi Morris'tir.

Türk ailesi ise Emine ve kızı Zeynep'ten oluşmaktadır. Emine, kocası Almanya'da olduğundan pansiyonlarını kızıyla beraber işletmektedir. Bu aileden de savaşa katılanlar olmuştur: Hasan Dede ve kardeşleri Mehmet Ağa ve Mustafa Çavuş.

Peggy ile annesi yakın bir dönemde Çanakkale'ye gitme kararı almışlardır. Bu durum özellikle Peggy için çok önemlidir. Peggy bu savaşı ve bu savaşla ilgili anıları, büyükannesi Tilly'den dinlemiştir. Tilly ise tam bir İngiliz hayranıdır. Ona göre, bu savaş için İngiltere Kraliçesi onlardan yardım istemiş; onlar da bunu seve seve yerine getirmişlerdir. Tilly, bu savaşın anlamını bu sebeple 
pek sorgulamaz; ancak durum Peggy için böyle değildir. $O$, bu savaşın nedenini, nasılını da sorgulamaktadır. Bu yüzden Çanakkale ziyareti onun için çok önemlidir. Uçakla önce İstanbul'a gelirler. Oradan da Çanakkale'ye geçip Eceabat'ta bir pansiyona yerleşirler. Bu pansiyonda Zeynep ve annesinin işlettiği pansiyondur. Romanda iki ailenin ilk buluştuğu nokta burasıdır.

Zeynep de Peggy gibi bu savaşı aile büyüklerinden dinlemiştir. O, annesini kendisine anlattığ1 Hasan Dede'nin savaş anılarıyla büyümüştür. Zeynep de bu savaşı sorgulayanlardandır. Özellikle okuldaki öğretmeni Pınar Öğretmen ile bu durumu tartışırlar. Zeynep'e göre Avustralyalılar buraya kendileri için değil başka devletler istedikleri için gelmişlerdi ve bu onun için çok saçmaydı. Savaş ile ilgili aynı fikirleri paylaşan iki kız, pansiyonda tanışıp arkadaş olurlar. Zamanla da birbirlerine ne kadar çok benzediklerini fark ederler.

Peggy ve annesi Norma 25 Nisan günü, Avustralyalıların her sene, bu savaşta hayatını kaybedenleri andıkları Şafak Ayini için hazırlık yaparlar. Zeynep de onlara katılır. Ayin, Zeynep, Peggy ve Norma'yı derinden etkiler. Zeynep, Norma ve Peggy'den önce oradan ayrılır. Gördüklerini Pınar Öğretmen'e anlatır. Zeynep, öğretmenine Anzakların adeta bir maşa gibi kullanıldığını, Ruslar ve İngilizler için can verdiklerini anlatır. Çanakkale'de geçirilen zamandan sonra Peggy ve Norma'da aynı şeyleri düşünmektedirler. Peggy ve Norma'nın ziyaretlerinin sonu gelmiştir. Pazar günü kalkıp kahvaltı yaparlarken Pınar Öğretmen onlara müjdeli bir haber verir. Gelibolu bir Barış Parkı olarak düzenlenecektir. Bu güzel haberle Peggy ve Norma, Emine ve Zeynep'e veda edip ülkelerine dönerler. Yaptıkları bu ziyaret sonucunda Peggy'nin Çanakkale Savaşları ile ilgili düşünceleri değişmezken anne Norma'nın düşünceleri değişir. Yazar, romanı Peggy ve annesi uçağa bindiklerinde sonlandırır.

\subsection{Zeynep-Peggy}

Ele aldığımız romanın başkahramanları iki genç kızdır: Avustralyalı Peggy ile Türk kızı Zeynep. Roman boyunca bu iki kahramanın birbirlerine olan benzerlikleri dikkat çekicidir. Öncelikle ikisi de savaş kavramını sorgulamaktadırlar.

“Peggy'nin bu savaşı sorgulaması, geçen yıl o yazıyı yazmaya çalışırken mi başlamıştı, yoksa büyük dedesinin anıların dinlerken mi? Tam olarak bilmiyordu. Büyük annesine ilk kez, "Bilmediği bir ülkeye gidip tanımadiğı ulusa karşı savaşmanın ne anlamı var ki?" diye sorduğunda, evin içine bomba düşmüş gibi olmuştu.

Peggy, "Savaşmanın bir amacı olmalı” diye sürdürmüş̧ü sözlerini: “Ölmeyi de öldürmeyi de geçerli kllacak kadar önemli bir amaç.” (Ural, 2006:14)

İlerleyen sayfalarda Peggy, annesiyle girdiği diyaloglarda da savaşı sorgulamaya devam eder. Savaşı bir cinayet olduğunu, ancak vatan savunmasının kutsal olduğunu belirttiği diyaloglar göze çarpmaktadır.

“-Ne boşuna bir ölüm değil mi, İngiltere’ye destek olacağız diye kalklp buraya gelenler için?

-Savaşlar hep birilerinin ölmelerini gerektirir, dedi Norma.

-Savaş, ölüm demektir. Dün okuduğumuz kitap, Mustafa Kemal'in "Savaşs bir cinayettir", dediğini yazmiyor muydu?

-Her düzenin kuralları vardır, bilirsin. Savaş da bir düzen. Ölmek ve öldürmek, kurallarından. Gene Mustafa Kemal, Gelibolu Savaşları'nda askerlerine, "Size savaşmayı değil, ölmeyi emrediyorum," demiş.

Peggy heyecanla karşı çıktı. "Ama o başka" dedi, "çok başka". Onlar için, kendi topraklarını korumak söz konusuydu, vatanlarında özgür yaşamak uğruna çarpıştılar. Böyle bir amaç için ölmek doğru."

“Anllyor musun?" diye üsteleyerek sordu. "Ölmeyi seçen kendileri olunca başka. Üzücü olan, yanlış olan, buna başka bir ülkeden, başka birilerinin karar vermesi. Bu yanlış. Çok yanlış."”,

Görüldüğü gibi Avustralyalı Peggy, savaş kavramını, kendisinden yaşça büyüklerle bile tartışmakta, fikirlerini açıklıkla ortaya koymaktadır. Bu durum, Peggy'nin benzeri olarak, Türk kızı Zeynep'te de görülür. Zeynep de savaş kavramını, Pınar öğretmen ile girdiği diyaloglarda sorgulamakta ve kendince bazı sonuçlar çıkarmaktadır. 
“-Taa oralardan kalkıp geldiler, çünkü buraları alıp, Boğaz'dan geçmek ve İstanbul'u almak istiyorlardl. Öyle değil mi? Ruslar'a Boğazlar'ı, deniz yolunu açmak için.

-Evet öyle.

-Peki özgürlük bunun neresinde? Ŭgruna savaştıkları özgürlük, Ruslar'ın denize ulaşma özgürlüğ̈ mü?

\section{-Değil tabii. Olur mu öyle şey?}

-Ne özgürlüğ̈̈ bu, peki? Bizim olan toprakları almaya kalkmak, yurdunu savunan askerleri öldürmek, kime ne özgürlük sağlar ki? (Ural, 2006: 108)

Bu iki kız, savaş konusunda, aile büyüklerinden farklı düşünmektedir. Peggy, savaşı babasından dinlemiş olan büyükannesi Tilly ve annesiyle bir çatışma yaşarken Zeynep de bu çatışmayı annesi ile yaşamaktadır.

“Büyükanne Tiily, Gelibolu Savaşları'nı tekrar tekrar anlatırdı. Hiç sıkılmaz, dinleyenlerin sıkılabileceği aklına gelmezdi. Ama o gün öyle olmadı. Peggy, savaşın anlamın sorguladıktan sonra büyükanne, yalnızca babasının söylediklerini tekrarlayıp sustu. Bir süre sessizlik içinde çaylarını içtiler.

Işste o zaman Peggy, büyükannesiyle tartışmaya girmenin boşuna olduğunu düşünüp başka bir şey sormadı. O hâlâ 20. Yüzyılın başlarında yaşıyor gibiydi. Duyguları, düşünceleri hiç değişmemiş gibiydi. Oysa artık 21. Yüzyıla girmek üzereydiler. Değerler, görüşler, düşünceler, insanlar; her şey çok başkaydl." (Ural, 2006: 17)

Türk kızı Zeynep de aynı çatışmayı savaşı aile büyüklerinden dinleyen annesi ile yaşamaktadır.

“Emine evde hep savaş öyküleri dinleyerek büyümüştü. Şimdi Zeynep, onca yıl duyduklarından ayrı şeyler söylüyor, aklını karıştırıyordu.

\section{Zeynep, annesini bildiğinden döndürmenin güçlüğünü anladı” (Ural, 2006: 33)}

Peggy ile Zeynep arasındaki benzerlikler, fizikî görünümlerinde de kendini gösterir. Peggy'nin pansiyonlarına geldiği ilk gün, Zeynep'in dikkatini çeken şey, ikisinin fiziksel olarak birbirlerine benzedikleridir.

“Bu küçük, eski görünüşlü pansiyona girer girmez Peggy’nin ilk gözüne çarpan da, kapının sağındaki yazı masasını düzenleyen kız oldu. Ayn yaşta olmalıydılar. Üstelik kendisine benziyordu. Yüz hatları hemen hemen kendininkilerle aynı, yalnı gözleri koyu renkti.

"Anne geldiler!" diye içeri seslendi Zeynep. Tekrar kapıya baktığında ise Peggy'nin kendisine çok benzediğini fark etti." (Ural, 2006: 46)

Romanın başkahramanlarının benzerlikleri, bunlarla da sınırlı kalmıyor. Fiziksel, fikirsel benzerliklerin yanında bu iki kızın zevk ve tercihleri de birbirine benzemektedir.

“Konak Pansiyon'a girdiği andan beri, her karşılaştıklarında "Bana ne kadar benziyor” diye düşündüğü Peggy, aldiğı kartı kendisine uzatınca Zeynep gözlerine inanamadı. Bu, Çanakkale vapur iskelesini gösteren bir fotoğraftı...

Ne var ki, Zeynep ne zaman birisine kart gösterecek olsa, Çanakkale'yi gösteren birçok resim arasından hep bunu seçerdi. En beğendiği buydu. Babasina, ăgabeyi Mehmet'e ve Almanya'daki başka birkaç akrabaya, bayramlarda hep aynı karttan göndermişti.

İşte Zeynep'i şaşırtan buydu. Demek Peggy, onca kart arasından bunu seçmişti. Öyleyse yalnız görünüşleri değil, zevkleri de benziyordu." (Ural, 2006:73)

Peggy ile Zeynep arasındaki benzerlikler, sadece somut dünya ile sınırlı değil. Zaman ve mekândan bağımsız olunan rüyalarda da bu iki kızın ortak yönleri göze çarpmaktadır. Romanın 
“Gerçek Mi?” adlı bölümde uyuklayan Peggy ile Zeynep'in rüyaları anlatılmaktadır. İki kız da rüyalarında kendilerini savaşın içinde görmektedirler. İkisi de dedelerini bulup onlarla konuşmaktadırlar. Bu sayede romanın başkahramanları savaşın içine de girmiş oluyor. Bu durumun dikkate değer yanı, yazarın varmak istediği evrensellik mesajına uygun bir şekilde kurgu yapmış olmasıdır. Bu sayede yazar hümanist bir yaklaşım da sergilemektedir.

Roman boyunca çeşitli durumlarda bulunan kızların, bu durumlar karşısındaki tepkileri bile benzerdir. Bu benzerlik rastlantısal veya sistemsiz olarak kurgulanmış benzerlikler değildir. Farklı kültür çevrelerinde yetişmiş de olsa aynı durumlarda aynı tepkilerin verilebileceği dile getiriliyor. Tabii, bu kurgu yazarın varmak istediği evrensellik anlayışına oldukça uygun görünmektedir. kază̆ını.

"Peggy annesinin verdiği uzun yün çorapları giydi. Üstüne pantolonunu, onun üstüne de

"Lahana gibi oldum" diye söylendi, "kat kat..."

Aynı dakikalarda, bir üst kattaki odasında Zeynep de "Kat kat" diye söyleniyordu içinden, soğan gibi giyinmem şart mi?" (Ural, 2006: 76)

Tüm bu benzerlikler, tesadüfler, yazarın evrenseli yakalama çabasının ve hümanist bakış açısının bir sonucudur. Şafakta Yanan Mumlar romanındaki benzerlikler, Zeynep ile Peggy'ninkilerle sınırlı değildir. Bu iki kızın aile fertleri, yapıları, geçmişleri de birbirlerine benzer özelliklerle okuyucuya aktarılmıştır.

\subsection{Tilly-Gülbahar Nine-Emine}

Tilly ile Gülbahar Nine, roman başkahramanlarının büyükanneleridir. Onlar romanda geçmişi yaşamış insanlar olarak yer alırlar. Roman boyunca anlatılan savaşı yakından yaşamışlardır. Bu iki yaşı kadın Çanakkale Savaşları'na sevdiklerini göndermişlerdir. İkisinin de babası bu savaşa katılmıştır. Bu sebeple romanda savaş kavramına objektif ve hümanist açıdan bakamazlar. $\mathrm{Bu}$ konumları sebebiyle bu iki karakter Peggy ile Zeynep'in çatışma yaşadığı kişilerdir. İkisi de savaşı aile büyüklerinden dinlemişlerdir. Dinledikleri bu savaş anılarını da sıklıkla kızlarına anlatmışlardır.

“"Sonra bir gün savaşa ara vermişler" diye anlatmayı sürdürdü büyükanne, "tabii, bunları hep Bill Amca'dan dinledik. Babam hiç söz etmezdi ki savaştan. Bill amca gene bir akşam bize yemeğe gelmişti. Yemek öncesi içkilerini içerken ben de onların yakınında olmaya, konuştuklarını dinlemeye çalışırdım. Galiba annem de onun için her şeyi önceden hazırlar, onların yanından hiç ayrllmazdı. Bill Amca Gelibolu anılarını bir masalmış gibi anlatırdı."," (Ural, 2006: 50)

Tilly'nin bu savaş karşısındaki duruşu kesindir. Ona göre, babası ve savaşa katılan tüm Avustralyalılar, İngiltere Kraliçesine olan bağlılıklarını gösteriyorlardı. Birleşik Krallık onlardan yardım istemişti ve buna hayır demek, büyük saygısızlık olurdu. Tilly için savaş budur. O, savaşın insanî ve vicdanî yönünü pek düşünmez. Onun için önemli olan Kraliçe'ye duyulan bağl1lı̆̆n kanıtlanmasıdır. Bu bakımdan Tilly’nin görüşü sabittir.

"Sözlerini bitirince duvardaki resme baktt. Ingiltere Kraliçesi, koyu renk çerçeveli tablonun içinden kendisine gururla gülümser gibiydi. Doğruydu. Babası, yeri geldikçe hep aynı sözleri tekrarlamıştı: "Yapmamı gereken buydu. Ingiltere'ye destek olmamı gerekiyordu. Bizden bekleneni yaptık.", (Ural, 2006: 17)

Gülbahar Nine de savaş hakkındaki bildiklerini babası olan Hasan Dede'den dinleyerek öğrenmiştir.

"Gülbahar Nine de hep "İngilizler" derdi Gelibolu Savaşları'ndan söz ederken. "İngilizler ateş açmış" ya da "Bizimkiler İngilizleri durdurmuş" diye anlatırdı babasının anılarını. Öyle dinlemişsti Hasan Dede'den." (Ural, 2006: 33)

Tilly ile Gülbahar Nine birbirine denk kurgulanmıştır. İkisinin savaş karşısındaki tutumu bile birbirlerininkilere benzemektedir. Gülbahar Nine de bu konuda Tilly gibi kesindir. Bakış açısını sabitlemiştir. Onun da kendine göre doğruları vardır. 
“... Gülbahar Nine, babasından dinlemişti Çanakkale Savaşları’nı. En doğru öyküleri onun anlattı̆̆ına inanırdl, çünkü babası savaşın içinde yaşamışıtı.” (Ural, 2006:35)

Yukarıda verdiğimiz misaller Tilly ile Gülbahar Nine'nin benzerliklerini ortaya koyarken, Zeynep'in Gülbahar Nine'ye, Peggy'nin ise Tilly'ye karşı olan tutumlarındaki ortak noktayı gözler önüne sermektedir. Romanın başından sonuna kadar savaş kavramını sorgulayan bu iki çocuk büyüklerinden farklı düşünmektedirler. Bir anlamda Zeynep ile Peggy modernizmi, Tilly ile Gülbahar Nine ise gelenekçiliği temsil etmektedirler. Yazar da çatışmasını bu müsait ortamda oluşturmuştur. Tilly’e göre; "Bugünkü gençler çok başka düşünüyor" dur. (Ural, 2006:19). Peggy’nin gözünden Tilly ise, hala yirminci yüzyılın başında yaşıyor gibidir. Duyguları, düşünceleri hiç değişmemiştir. Peggy’ye göre artık yeni bir yüzyıla girilmekteydi ve bu yüzyılda değerler, görüşler, düşünceler, insanlar ve her şey değişmiş ve başkalaşmıştı.

Görüldüğü üzere Tilly ve Gülbahar Nine, savaşı dinleyerek büyümüşlerdir. $\mathrm{Bu}$ da farkl1 coğrafyalarda da olsa aynı acıyı yaşayan insanların birleştiği konunun ortak olduğunu gösteriyor. Yazarın bunu yaparken vermek istediği mesaj; farklı görünseler de farklı coğrafyalarda yaşasalar da tüm insanlığın ortak sıkıntıları, değerleri vardır, şeklindedir. Bunu da kullandığı roman kişilerini benzer kurgulayarak elde etmiştir. Yazar, adeta romanda Peggy'ye sordurduğu, "Acaba Zeynep'in ailesi de Gelibolu Savaşları'nda var mıydı" diye düşündü. "Acaba onlar nasıl insanlardı?" (Ural, 2006: 49) sorusuna cevabı, kendi kurgusuyla vermektedir. Romanı okuduğumuzda bu sorunun cevabını almaktayız: Evet, Zeynep'in ailesi de bu savaşta vardı ve Peggy'nin ailesindekilere benzer insanlard1.

\subsection{Tilly’nin Babası-Moris Amca-Bill Amca-Hasan Dede-Mustafa Çavuş-Mehmet Ağa}

$\mathrm{Bu}$ grupta sayacağımız kişiler, savaşın içinde yer almış kişilerdir. Düşman iki topluluğun askerleridirler. Yazar özellikle bu iki grubun savaş zamanı yaşadıklarını gerek geriye dönüş tekniğiyle gerekse de diğer karakterlerin ağızlarından aktararak iki tarafa da değiniyor. Burada önemli olan birbirine düşman bu iki grubun yaşadıklarının aynılığıdır. İki grup da büyük sıkıntılar çekmiş, ölüler, yaralılar vermişlerdir. Romanda ayrıca cephe önü anlatılarak cephe gerisi hakkında da bilgi verilmektedir. Kiminin nişanlısı, kiminin oğlu, kiminin kocası, kiminin babası, ağabeyi kardeşidir savaşta olan. Bu durum savaşın iki tarafi için de geçerlidir. Renkler ve 1rklar farklı olsa dahi sevilen insanlardan uzak düşmenin yüreklerde bıraktığı acı birdir. Cephe gerisi için de bu durum geçerlidir. Sevdiklerinden habersiz ve endişe içindeki insanların paylaştığı duygular da birdir.

$\mathrm{Bu}$ grupta dikkatimizi çeken diğer bir benzerlik, savaşan isimlerin birbirlerinin akrabaları ya da kardeşleri olmasıdır.

“Üç kardeş Gelibolu'da birlikte çarpışmışlardl. Mehmet Ăga orada şehit olmuş, Hasan Dede’yle Mustafa Çavuş da Sakarya Savaşı'nda şehit olmuş, Hasan Dede ise Yemen'de çarpışırken bir kolunu kaybedip gelmişti." (Ural, 2006: 33)

$\mathrm{Bu}$ akrabalık ilişkisi, Anzak tarafı için de geçerlidir. Yazarın burada da benzer bir kurgulama yaptığı dikkati çekmektedir. Tilly, romanın bir yerinde şöyle anlatılır;

“Babası Gelibolu Savaşları’na katılmış, resimlerinden tanıdı̆̆ amcası ise orada ölmüşı̈̈.” (Ural, 2006: 15)

Burada benzerlik sadece savaşa katılanların akraba olmaları değildir. Yazar bu şekilde karakterler arasında bir benzerlik sağlamıştır. Ancak alıntıladığımız metinlerden hareketle iki grup için bir benzerlik daha buluyoruz. İki tarafın da savaşta hayatını kaybetmiş aile bireyleri vardır. Coğrafyalar, diller, inançlar farklı olsa da savaşta ölenin yakınlarının yaşadığı acı aynıdır. Yazar burada bu konuya da değinmek istemiş̦tir. Bu sayede yazar, kitabın ön sözünde belirttiği, "ölenin öldürenden farklı olmadı̆̆l, ölenin de öldürenin de insan olduğunu göstermek, savaşların sonunda kazanan tarafin bile çok şey kaybettiğini göstermek ve her zaferin perde arkasında yoğun acıların yaşandığını anlatmak" (Ural, 2006: 5-6) amacına yönelik bir kurgulama ve karakterizasyona gitmiş̧ir. Nitekim Bill Amca savaş ile ilgili anılarından bahsederken Türk askerleri için, "Bizim gibi genç çocuklardı... Mert bakışlı, 
dürüst yüzlü delikanlılardı" (Ural, 2006: 51) diyerek iki tarafın birbirlerine olan benzerliğini dillendirmektedir.

"Aynı yaşlarda, geride bekleyenleri olan gençler... Kimi yaralı ya da sağlam, bir gün eve dönecek. Kimi bıraktı̆̆ yerleri, bıraktı̆̆l kişileri bir daha göremeyecek. Ortak bir kaderin karşı karşıya getirdiği gencecik insanlar..." (Ural, 2006: 52).

\section{SONUÇ}

Bir gençlik romanı olan Şafakta Yanan Mumlar, çocuklara ve gençlere savaşın acı yönünü göstermek, barışın güzelliğini, bu sayede dile getirmek adına kaleme alınmıştır. Bu çerçeve içinde yazar Serpil Ural, hümanist bir yaklaşım sergilemektedir. Bu yaklaşım çocuk ve gençlik edebiyatı ürünleri için elzemdir. Yaptığımız inceleme sonucunda yazarın tasarladığı vaka kuruluşunu, kurguyu ve karakterleri, hümanist anlayışın belirlediği ortaya çıkmaktadır. Roman bu kavram üzerine şekillendirilmiştir. Bu kavram romana yönünü veren kavram olmuştur. Böylelikle evrensele ulaşılmaktadır. Serpil Ural da romanda karakterlerin ağzından bu görüşü gündeme getirmektedir.

"Onlara ögretilmesi gereken yalnızca evrensel doğrular" diye düşündü Norma. "Yılların, çă̆ların değiştiremediği; insanın, yaşamın doğasından kaynaklanan doğrular. Yapılması gereken, bunlarl, değişen değerlerden ayırt edebilmek ve yeni yetişen kuşaklara aktarmaktır." (Ural, 2006: 144)

\section{KAYNAKÇA}

BORATAV P. N. (2000), 100 Soruda Halk Edebiyatı, Gerçek Yayınları, İstanbul.

CEVİCİ, A. (1999), Felsefe Sözlüğü, Paradigma Yayınları, İstanbul.

ÇETIŞLİ, İ. (2010), Batı Edebiyatında Edebi Akımlar, Akçağ Yayınları, Ankara.

DEMIRCAN, C. (2006), “TÜBİTAK Çocuk Kitaplığı Dizisindeki Kitapların Dış Yapısal ve İç Yapısal Olarak İncelenmesi”, Mersin Üniversitesi Eğitim Fakültesi Dergisi, Cilt:

2, Sayı: 1, Haziran, s. 12-27.

GÖKÇE, B. ve Sis, N. (2001), “Gülten Dayığlu'nun Çocuk Öykülerinin "Hikaye Haritası" Yöntemine Göre İncelenmesi ve Genel Bir Değerlendirme”, Turkish Studies, Volume 6/3, Summer 2011, s. 1925-1949. 
KAVKAV, C. (1994), Eğitim ve Edebiyat, Ankara Üniversitesi Basımevi, Ankara.

MAT, C. (2007), "Çanakkale Muharebelerini Konu Edinen Romanlar Üzerine”, Balıkesir Üniversitesi Sosyal Bilimler Dergisi, Cilt: 17, Sayı: 1, Haziran 2007, s.81-100.

OĞUZKAN, A. Ferhan (2003), Çocuk Edebiyatı, Anı Yayıncılık, Ankara.

TAN, Nail (1995), "Yunus Emre ve 72 Millet”, Uluslararas1 Yunus Emre Sempozyumu Bildirileri, 710 Ekim 1991, Ankara, s. 337-344.

URAl, S. (2006), Şafakta Yanan Mumlar, Bilgi Yayınevi, İstanbul.

YARDIMCI, M. ve Tuncer, H. (2002), Eğitim Fakülteleri İçin Çocuk Edebiyatı, Ürün Yayınları, Ankara.

ZEKIYAN, B. (1982), Hümanizm (İnsanc1l1k) Düşünsel İçlem ve Tarihsel Kökenler, İnkılap ve Aka Yayınları, İstanbul. 